\title{
Relationship between light absorption by pelagic particles and microplankton metabolic activity in the Gulf of Lions
}

\author{
Susana Agustí, Antonio Cruzado \\ Centre d'Estudis Avançats de Blanes, Camí de Santa Bárbara s/n, E-17300 Blanes, Girona, Spain
}

\begin{abstract}
We examined the relative contribution of autotrophic and non-algal particles to light absorption in marine waters in the Gulf of Lions (NW Mediterranean), and the relationship between light absorption by sestonic particles and their gross biological activity, as measured by electron (ETS) transport activity. Our results showed that non-algal particles make an important, often dominant, contribution to light absorption by sestonic particles. The potential respiration rates (ETS activity) of seston were found to be remarkably related to the light absorption coefficient of sestonic particles, $a_{\mathrm{p}(400)}$, as described by the equation ETS activity $\left(\mu \mathrm{O} \mathrm{O}_{2} \mathrm{l}^{-1} \mathrm{~h}^{-1}\right)=14.1 a_{\mathrm{p}(400)} 0.92\left(\mathrm{r}^{2}=0.65, \mathrm{n}=37, \mathrm{p}<\right.$ $0.001)$. This relationship was stronger than that to light absorption by either algal or non-algal particles alone, as would be expected from the contribution of both particle types to seston metabolism. Our findings suggest a potential for the assessment of gross metabolism of marine planktonic communities from remotely-sensed optical properties.
\end{abstract}

\section{INTRODUCTION}

The chlorophyll a concentration and primary production of marine waters are predictable from remotelysensed optical properties. Similarly, the biogenic content of the photic zone of marine waters should be predictable from optical properties, because most lightabsorbing materials there, whether particulate or dissolved, are of biological origin (Morel 1988). These comprise planktonic organisms, both photosynthetic and non-photosynthetic, and biogenic detritus, which may also have an important contribution to light attenuation in the sea (Iturriaga \& Siegel 1989, Spinrad et al. 1989, Bricaud \& Stramski 1990, Cho \& Azam 1990). Thus, light absorption in the sea at certain wavelengths may be better related to the biomass of all light-absorbing particles than to that of photosynthetic organisms alone (Morel 1988, Spinrad et al. 1989).

Gross planktonic metabolism is also strongly related to total planktonic biomass, as demonstrated by strong relationships between particulate organic carbon (including that of detritus) and planktonic respiration (e.g. Williams 1981, Courties et al. 1989). Thus, we hypothesize a positive, indirect relationship between light absorption and the bulk metabolism of planktonic communities. This hypothetic relationship would, if confirmed, extend the power of optical properties to monitor biological processes in the ocean even further.

Here we examine the relative contribution of autotrophic and non-algal (heterotrophic organisms and detritus) particles to light absorption in marine waters in the Gulf of Lions (NW Mediterranean), and test the hypothesized relationship between bulk metabolic activity and light absorption by pelagic particles.

\section{METHODS}

The optical properties of seston within the photic layer in the Gulf of Lions were examined on particles collected on filters. The bulk metabolic activity of sestonic particles was described by their potential respiration, as the electron transport activity of the particulate fraction (ETS activity; Packard 1971). ETS activity is closely related to realised respiration (Packard \& Williams 1981), and can be measured at low biomass, where direct measurements of respiration may have large error (Packard \& Williams 1981). The relative contribution of phytoplankton and non-algal particles to light absorption was assessed following the method of Bricaud \& Stramski (1990). Phytoplankton abundance was represented by the chlorophyll a (chl a) concentration of the waters sampled. 
Sampling at the Gulf of Lions was conducted during the Rhodiber-90 EROS 2000 cruise (14 to 29 September 1990) aboard the RV 'Garcia del Cid'. Water samples were collected using a 301 Niskin bottle in the upper $120 \mathrm{~m}$ at Stations RA1, RA6b, RA7, RB2, RC2, RC4, RD2, RE1, RF2, and R1 (Cruzado et al. 1991), which comprise oceanic and coastal Mediterranean waters and riverine waters discharged by the Rhône river. Sampling depths were selected upon examination of the distributions of salinity and temperature (CTD). Aliquots of each sample were used to measure ETS activity, chl a concentration, and total-particle light absorption at fixed wavelengths across the PAR band. Samples for the different analyses were pre-filtered through a $240 \mu \mathrm{m}$ net to exclude large zooplankton.

ETS activity was measured on seston collected by filtering water (2 to $10 \mathrm{l}$, depending on seston concentration) through Whatman GF/F fibre-glass filters. Filters were immediately frozen in liquid nitrogen until enzymatic analysis at the laboratory. ETS activity, expressed as $\mu \mathrm{O}_{2} \mathrm{~h}^{-1} \mathrm{I}^{-1}$, was measured at sea temperature (CTD) following the tetrazolium reduction technique (Packard 1971) as modified by Kenner \& Ahmed (1975). Standardization of INT-formazan specific absorbance coefficient with NADH (Packard unpubl.) yielded a value of 0.2 for the INT-formazan specific absorbance coefficient at room temperature. The chl a concentration was measured in $250 \mathrm{ml}$ aliquots filtered through Whatman GF/F filters. Filters were homogenized prior to chl a dark extraction for ca $4 \mathrm{~h}$ in acetone, and were kept refrigerated until measurement in a Turner Designs fluorometer (Parsons et al. 1984).

Measurement of light absorption by sestonic particles (phytoplankton, detritus, and other particles) followed Mitchell \& Kiefer (1988). Seston was concentrated by filtering a variable volume of water $(2$ to 101$)$ through Whatman GF/F filters. Filters were then placed on petri disks and kept wet and refrigerated in the dark until spectrophotometric measurements were made (within $4 \mathrm{~h}$ ). The optical density of the filters $\left(O D_{\mathrm{f}}\right)$ was measured in a spectrophotometer (LKB) using a clean-water saturated Whatman $\mathrm{GF} / \mathrm{F}$ filter as a blank. $O D_{\mathrm{f}}$ was measured at selected wavelengths within the PAR spectra $(400,440,500,520,580,625$, $675,700,750 \mathrm{~nm})$, representing those where peaks and valleys occur in most phytoplankton absorption spectra.

Particle light absorption $\left(a_{\mathrm{p}}, \mathrm{m}^{-1}\right)$ was calculated following the equation,

$$
a_{\mathrm{p}(\lambda)}=2.3 O D_{\mathrm{f}(\lambda)} C / V \beta_{(\lambda)}
$$

where $\lambda=$ wavelength $(\mathrm{nm}) ; 2.3$ is the factor to convert base 10 logarithms to natural logarithms; $C=$ clearance area of the filter $\left(\mathrm{m}^{2}\right) ; V=$ volume of seawater filtered $\left(\mathrm{m}^{3}\right) ;$ and $\beta=$ wavelength-dependent pathlength amplification factor of the filters. The absorption attributable to phytoplankton and non-algal particles at the wavelengths measured was estimated by an indirect method described by Bricaud \& Stramski (1990). The absorption coefficient by non-algal particles $\left(a_{\mathrm{d}}\right)$, was calculated as a negative exponential function of the wavelength (Bricaud \& Stramski 1990). This method was modified to use light absorption at $400 \mathrm{~nm}$ to calculate the coefficients of the exponential equation instead of $380 \mathrm{~nm}$ as recommended by Bricaud \& Stramski (1990). This modification was found, using an independent data set (Agustí unpubl.), to have no significant influence on the estimated absorption coefficients.

The light absorption coefficient for phytoplankton $\left(a_{\mathrm{ph}}\right)$ was then calculated (at each wavelength) following the expression,

$$
a_{\mathrm{ph}}=a_{\mathrm{p}}-a_{d}
$$

We used light absorption at $675 \mathrm{~nm}$, an absorption peak of chl $a$, to examine absorption by phytoplankton (e.g. Morel \& Bricaud 1981). The measured particulate absorption coefficients at $400 \mathrm{~nm}$ were selected to examine the compound absorption of the different types of sestonic particles. This selection is based on the fact that the light absorption coefficients (PAR band) of different types of sestonic particles (e.g. bacteria, detritus) are greatest at $400 \mathrm{~nm}$, which does not correspond to a pigment-related light absorption peak (e.g. Morel \& Bricaud 1981, Morel \& Ahn 1990, 1991).

The relationships between variables were described using least-squares linear regression analysis. Logarithmic (base 10) transformation of the variables was found to be necessary to avoid heteroscadicity (Draper \& Smith 1966).

\section{RESULTS}

Chl a concentrations, particle light absorption, and potential respiration rates ranged greatly (Table 1), reflecting the high biological heterogeneity attributable to the discharge of the river Rhône in the Gulf of Lions (e.g. Cruzado \& Velasquez 1990). Chl a concentrations, particle light absorption, and potential respiration rates were greatest at stations receiving a substantial discharge of river water.

Non-algal particles (e.g. detritus and heterotrophic organisms) made an important contribution to $a_{\mathrm{p}}$ in most samples (Fig. 1), and the contribution of phytoplankton to $a_{\mathrm{p}(\lambda)}\left(\right.$ i.e. $\left.a_{\mathrm{ph}\left(\lambda_{\lambda}\right)}\right)$ tended to be greater at 675 $\mathrm{nm}$ than at $400 \mathrm{~nm}$ (Wilcoxon sign-test, $\mathrm{p}<0.01$; Table 1). Thus, absorption by non-algal particles added considerable error to the relationship between chl a concentration and light absorption by particles. This rela- 
Table 1 Maximum, minimum and mean values for biological and optical parameters measured in the Gulf of Lions. $a_{p}(\lambda)$ total particulate matter light absorption; $a_{\mathrm{ph}(\lambda)}$ : phytoplankton light absorption; $\mathrm{a}_{\mathrm{d}(\lambda)}$, non-algal matter light absorption; $\lambda=$ 400 and $675 \mathrm{~nm}$ (wavelength); $\mathrm{n}=37$

\begin{tabular}{|c|c|c|c|}
\hline & Maximum & Minimum & Mean \\
\hline Chl a $\left(\mathrm{mg} \mathrm{m}^{-3}\right)$ & 5.2 & 0.03 & 0.6 \\
\hline ETS activity $\left(\mu \mathrm{l} \mathrm{O}_{2} \mathrm{l}^{-1} \mathrm{~h}^{-1}\right)$ & 19.0 & 0.14 & 1.18 \\
\hline$a_{: 00)} \quad\left(m^{-1}\right)$ & 0.418 & 0.008 & 0.052 \\
\hline$a_{p(675)} \quad\left(\begin{array}{ll}m^{1} & \end{array}\right)$ & 0.144 & 0.002 & 0.020 \\
\hline$a_{d(400)} \quad\left(m^{1}\right)$ & 0.238 & 0.000 & 0.030 \\
\hline$a_{d(675)} \quad\left(m^{i}\right)$ & 0.090 & 0.000 & 0.007 \\
\hline$a_{p h(400)} \quad\left(m^{-1}\right)$ & 0.180 & 0.003 & 0.022 \\
\hline$a_{p h(675)} \quad\left(m^{-1}\right)$ & 0.116 & 0.0007 & 0.012 \\
\hline
\end{tabular}

tionship was, therefore, stronger $(\mathrm{r}=0.92$ and 0.84 , at 675 and $400 \mathrm{~nm}$, respectively) when examining light absorption by phytoplankton $\left(a_{\mathrm{ph}(\lambda)}\right)$ than that to bulk light absorption by sestonic particles $\left(a_{\mathrm{p}(\lambda)}, \mathrm{r}=0.81\right.$ and 0.67 at $675 \mathrm{~nm}$ and $400 \mathrm{~nm}$, respectively). These results

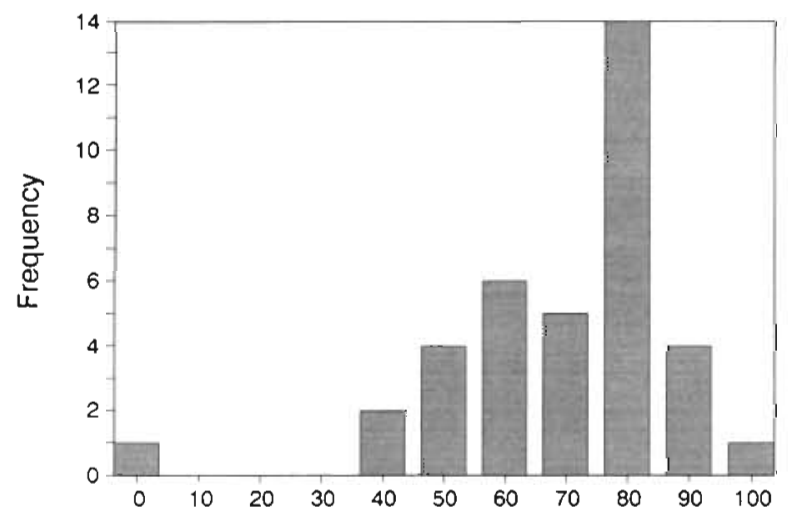

Percent light absorption by non-algal particles $(400 \mathrm{~nm})$

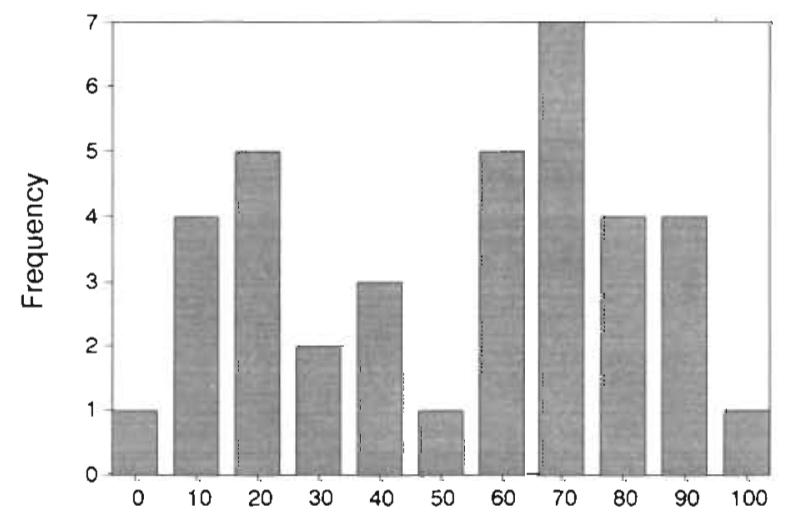

Percent light absorption by non-algal particles $(675 \mathrm{~nm})$

Fig. 1. Frequency distribution of light absorption percentages at 400 and $675 \mathrm{~nm}$ by non-algal particles in the Gulf of Lions support the adequacy of the empirical method used to partition the total absorption coefficient into an algal $\left(a_{\mathrm{ph}(\lambda)}\right)$ and detrital $\left(a_{\mathrm{d}(\lambda)}\right)$ component (Bricaud \& Stramski 1990).

The relationship between chl a concentration and ETS activity was weak $(r=0.65, p<0.05)$. The weakness of this relationship may reflect the importance of non-algal particles (e.g. heterotrophic organisms) in these waters, which should also contribute to seston metabolic activity. Thus, seston metabolic activity was significantly related to the light absoption coefficients $(400 \mathrm{~nm})$ of both algal $(\mathrm{r}=0.75)$ and non-algal $(\mathrm{r}=$ 0.69) particles (Fig. 2). Yet, the potential metabolic

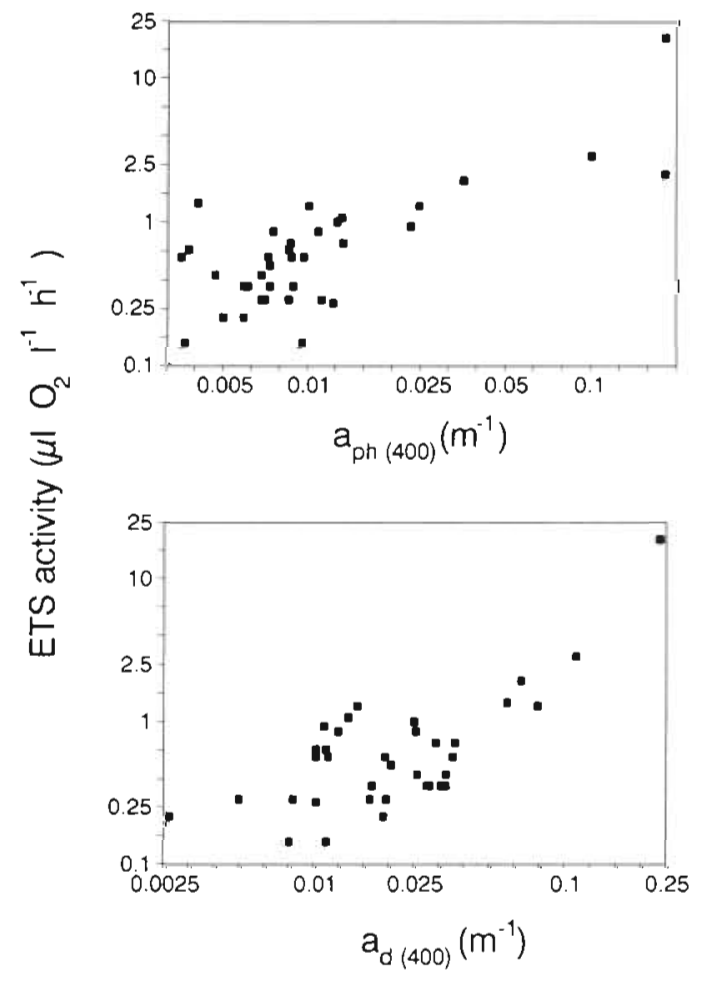

Fig. 2. Relationship between the ETS activity of microplankton and the light absorption coefficients of phytoplanktonic $\left(a_{\mathrm{ph}}\right)$ and non-algal $\left(a_{d}\right)$ particles at $400 \mathrm{~nm}$

activity of seston (ETS activity) was better correlated with the total particulate light absorption ( $\mathrm{r}=0.81$ ) than with its separate algal and non-algal components (Fig. 3). This relationship was best described by the regression equation,

$$
\text { ETS activity }\left(\mu \mathrm{l} \mathrm{O}_{2} \mathrm{~L}^{-1} \mathrm{~h}^{-1}\right)=14.1 \mathrm{a}_{\mathrm{p}(400)}{ }^{0.92}
$$

which reveals a remarkable, linear tendency (H0: slope $=1, p>0.10$ ) for the potential respiration of seston to increase as the particulate light absorption at $400 \mathrm{~nm}$ increases (Fig. 3). The strength of the relationship between potential seston metabolic activity and light 


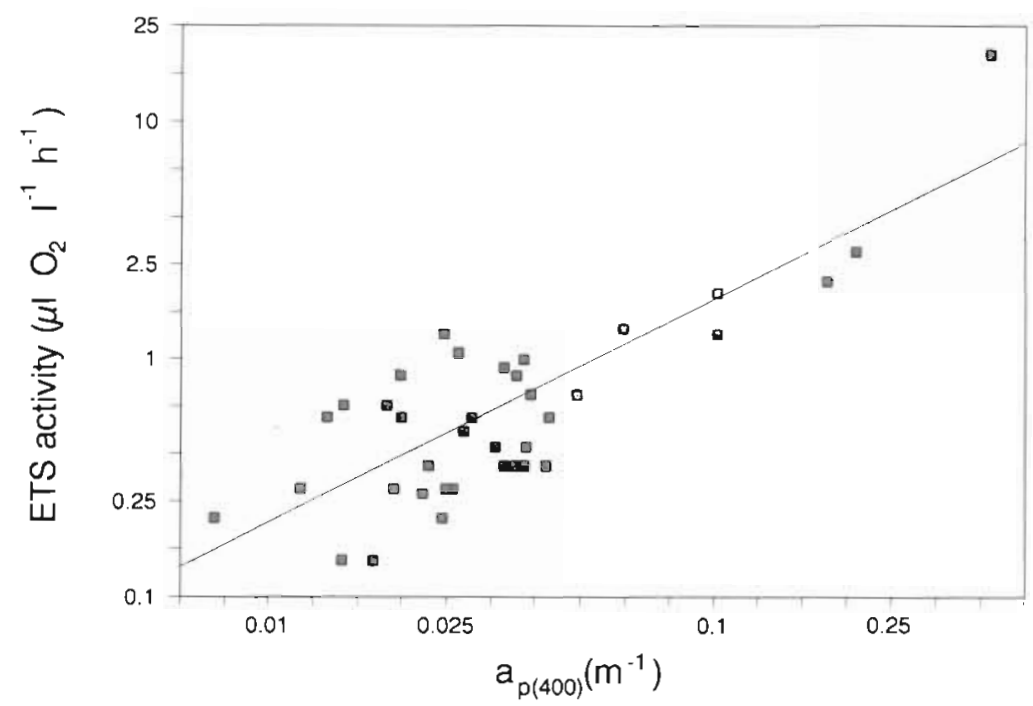

Fig. 3. Relationship between the ETS activity of microplankton and the light absorption by bulk particulate matter at $400 \mathrm{~nm}\left(a_{\mathrm{p}(400)}\right)$. Solid and dotted lines: Eq. (3) with $95 \%$ confidence limits absorption decreased significantly $(r=0.57)$ when particulate light absorption was measured at $675 \mathrm{~nm}$. The reason for this is probably that light absorption at this wavelength, which corresponds to an absorption peak

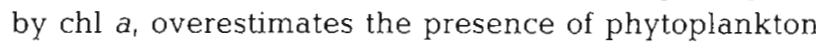
relative to heterotrophs, which may dominate planktonic metabolism (e.g. Williams 1981).

\section{DISCUSSION}

Our results show that non-algal particles make an important, often dominant, contribution to particulate light absorption in the oligotrophic waters of the Gulf of Lions (Fig. 1). This observation is in agreement with the increased importance of microheterotroph biomass (Bird \& Kalff 1984, Fuhrman et al. 1989) and bacterial particulate organic carbon (Cho \& Azam 1990) relative to phytoplankton biomass in oligotrophic waters.

The hypothesis that the optical properties of waters should allow the prediction of their bulk biological activity was supported by the significant relationship observed between the potential respiration rates and light absorption by sestonic particles (Eq. 3, Fig. 3). Detritic particles should not interfere with this relationship because detritus increases particulate light absorption but is also the focus of much microbial and heterotrophic activity (e.g. Fenchel 1970, Sorokin 1981).

Both respiration and light absorption by seston may be modelled as a combination of biomass-specific respiration and absorption, and biomass. Biomass-specific respiration rates and light absorption coefficients are influenced by many factors, such as habitat conditions and particle size and nature (e.g. Agustí 1991a, b, Ahrens \& Peters 1991). Yet, seston biomass is expected to be related both to seston respiration (Packard et al.
1981, Williams 1981, Iriarte et al. 1991) and light absorption (Morel 1988) when comparing waters across a broad range of seston biomass. This explains the remarkable, indirect relationship between light absorption and seston metabolism reported here (Fig. 3).

In summary, the results presented here demonstrate that the study of optical properties of marine particles allows inferences on the relative composition and gross metabolism of planktonic communities. Whether the relationship between particulate light absorption and seston metabolism reported here holds elsewhere needs be tested. If confirmed, this relationship would allow assessment of gross metabolism of planktonic communities from remotely-sensed optical properties.

Acknowledgements. This work was supported by the Spanish Ministry of Education and Science, as part of the EROS-2000 project, and by a Spanish Research Council (CSIC) postdoctoral fellowship to S. Agustí. We thank C. M. Duarte for useful criticism and 2 anonymous referees for their helpful comments.

\section{LITERATURE CITED}

Agustí, S. (1991a). Light environment within dense algal populations: cell size influences on selfshading. J. Plankton Res. 13: 863-871

Agustí, S. (1991b). Allometric scaling of light absorption and scattering by phytoplankton cells Can. J. Fish. Aquat. Sci 48: 763-767

Ahrens, M. A. Peters, R. H. (1991). Plankton community respiration: relationships with size distribution and lake trophy. Hydrobiologia 224: $77-87$

Bird, D. F. Kalff, J. (1984). Empirical relationships between bacterical abundance and chlorophyll concentration in fresh and marine waters. Can. J. Fish. Aquat. Sci. 41: 1015-1023

Bricaud, A., Stramski, D. (1990). Spectral absorption coefficients of living phytoplankton and nonalgal biogenous matter: a comparison between the Peru upwelling area and the Sargasso Sea. Limnol. Oceanogr. 35: 562-582 
Cho, B. C., Azam, F. (1990). Biogeochemical significance of bacterial biomass in the ocean's euphotic zone. Mar. Ecol. Prog. Ser. 63: 253-259

Courties, C., Shi, J., Ning, X., Chen, Z., Lasserre, P. (1989). Respiration rates in the Changjiang River mouth and the adjacent East China Sea: relations with bacteria and phytoplankton. Scientia Marina 53: 167-173

Cruzado, A., et al. (1991). Report of the cruise Rhodiber 90 , EROS 2000 project. Water Pollution Research Reports, CEC (in press)

Cruzado, A., Velasquez, Z. (1990). Nutrients and phỵtoplankton in the Gulf of Lions, northwest Mediterranean. Contin. Shelf, Res. 10: 931-942

Draper, N. R., Smith, H. (1966). Applied regression analysis. John Wiley \& Sons, New York

Fuhrman, J. A., Sleeter, T. D., Carlson, C. A., Proctor, L. T (1989). Dominance of bacterial biomass in the Sargasso sea and its ecological implications. Mar. Ecol. Prog. Ser. 57 : $207-217$

Fenchel, T. (1970). Studies on decompositon of organic detritus derived from turtle grass. Limnol. Oceanogr. 15: $14-20$

Iriarte, A., Daneri, G., Garcia, V. M. T., Purdie, D. A., Crawford, D. W. (1991). Plankton community respiration and its relationship to chlorophyll a concentration in marine coastal waters. Oceanol. Acta 14: 379-388

Iturriaga, R., Siegel, D. A. (1989). Microphotometric characterization of phytoplankton and detrital absorption properties in the Sargasso Sea. Limnol. Oceanogr. 34: 1706-1726

Kenner, R. A., Ahmed, S. I. (1975). Measurements of electron transport activities in marine phytoplankton. Mar. Biol. 33: $119-127$

Mitchell, B. G., Kiefer, D. A. (1988). Chlorophyll a specific absorption and fluorescence excitation spectra for phytoplankton. Deep Sea Res. 35: 639-663

This article was submitted to the editor
Morel, A. (1988). Optical modelling of the upper ocean in relation to its biogenous matter content (case I waters) J. geophys. Res. 93: 10749-10768

Morel, A., Bricaud, A. (1981). Theoretical results concerning light absorption in a discrete medium, and application to specific absorption of phytoplankton. Deep Sea Res. 28: 1375-1393

Morel, A., Ahn, Y (1990). Optical efficiency factors of freeliving bacteria: influence of bacterioplankton upon the optical properties and particulate organic carbon in oceanic waters. J. mar. Res. 48: 145-175

Morel, A., Ahn, Y. (1991). Optics of heterotrophic nanoflagellates and ciliates: a tentative assessment of their scattering role in oceanic waters compared to those of bacterial and algal cells. J. mar. Res. 49: 177-202

Packard, T T. (1971). The measurement of respiratory electron transport activity in marine phytoplankton. J. mar Res. 29: 235-244

Packard, T. T., Williams, P. J. LeB. (1981). Rates of respiratory oxygen consumption and electron transport in surface seawater from the northwest Atlantic. Oceanol. Acta 4: 351-358

Parsons, T. R., Maita, Y., Lalli, C. M. (1984). A manual of chemical and biological methods for seawater analysis. Pergamon Press, Oxford

Sorokin, Y. I. (1981). Microheterotrophic organisms in marine ecosystems. In: Longhurst, A. R. (ed.) Analysis of marine ecosystems. Academic Press, London, p. 293-342

Spinrad, R. W., Yentsch, C. M., Brown, J., Dortch, Q., Haugen, E., Revelante, N., Shapiro, L. (1989). The response of beam attenuation to heterotrophic growth in a natural population of plankton. Linnol. Oceanogr. 34: 1601-1605

Williams, P. J. LeB (1981). Microbial contribution to overall marine plankton metabolism: direct measurements of respiration. Oceanol. Acta 3: 359-364

Manuscript first received: November 14, 1991

Revised version accepted: July 2, 1992 